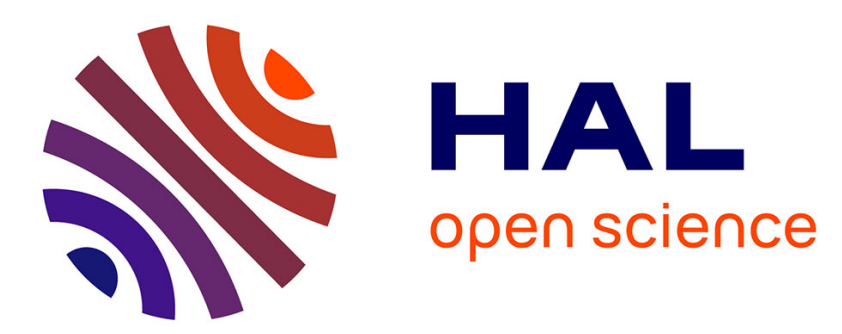

\title{
Crystallographical analysis of shear bands initiation and propagation in pure metals
}

Ph. Dubois, C. Rey

\section{To cite this version:}

Ph. Dubois, C. Rey. Crystallographical analysis of shear bands initiation and propagation in pure metals. Revue de Physique Appliquée, 1988, 23 (4), pp.696-696. 10.1051/rphysap:01988002304069600 . jpa-00245844

\section{HAL Id: jpa-00245844 https://hal.science/jpa-00245844}

Submitted on 1 Jan 1988

HAL is a multi-disciplinary open access archive for the deposit and dissemination of scientific research documents, whether they are published or not. The documents may come from teaching and research institutions in France or abroad, or from public or private research centers.
L'archive ouverte pluridisciplinaire HAL, est destinée au dépôt et à la diffusion de documents scientifiques de niveau recherche, publiés ou non, émanant des établissements d'enseignement et de recherche français ou étrangers, des laboratoires publics ou privés. 
CRYSTALLOGRAPHICAL ANALYSIS OF SHEAR BANDS INITIATION AND PROPAGATION IN PURE METALS $\mathrm{Ph}$. DUBOIS and C. REY

LPMTM, Université PARIS-NORD - Av. J.B. Clément 93430 - VILLETANEUSE

Our purpose was to determine conditions of shear bands initiation and propagation in pure copper single or polycrystals sollicited by tensile load and rolling.

Tensile tests were carried out "In situ" on single crystal orfented for double slip, thanks to a SEM. So we were able to determine the crystallographical nature of shear planes for various tensile axis orientation. Four orientations closed to $|001|,|-1,1,3|,|-1,1,2|$ and $|-1,1,1|$ were investigated. In all cases shear banding occured in the necking area after a mean strain of about $55 \%$. "In situ" observations pointed out that the localization mode was always caracterized by shearing in a very thin and planar band which width increased with increasing strain.

We had compared our experimental results to the prediction of the theoretical model developped by Pierce $|1|$ for rigid plastic materials. Founded upon Biot $|2|$, Hill and Hutchinson $|3|$ and Pierce Asaro and Needleman 4 works: It was assumed that crystal plasticity was rate independent, governed by Schmid's law, moreover the crystal was oriented in double ship deformation for tensile loading. For such a double orientation, a thin band of intense shearing limited by two nearly parallel planes grew in the crystal (fig.1). The transformation gradient rate $F$ was supposed to show an abrupt change of value in the thin band compared to the bulk one.

According to different authors, the discontinuity must be of the form :

$$
\Delta F=\vec{G} \otimes \vec{N}
$$

where $\vec{G}$ and $\vec{N}$ were the shearing vector and the unit normal to the band. Traction rates must be continuous across the shear planes, so one must have :

$$
\vec{N} . \Delta S=\overrightarrow{0}
$$

where $\mathrm{S}$ was the nominal stress tensor.

The misfit between experimental observations and theoretical predictions about crystallographical orientations of shear planes led us to introduce in the model some other parameters in order to take into account :

- the tensile test direction

- the stress field induce by the neck

- conditions on the strain field compatibility.

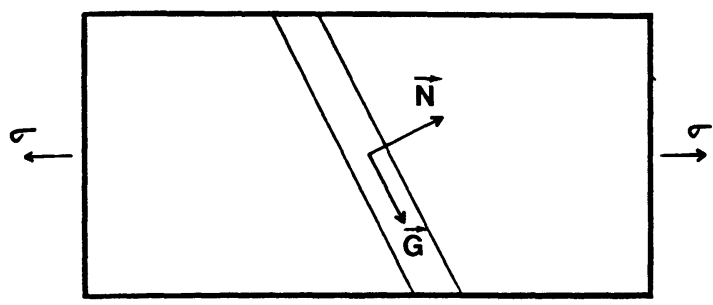

Fig. 1 Shear-band mode for tensile loading.
By these formulation we defined "potential shear systems" and are studying some criterions in order to determine the more favorable systems.

In polycrystals case, strained by rolling, fiducial grids were set down on the longitudinal section, in order to point out the displacement induced by shear bands and to analyse the interaction between shear bands and grain boundaries. A $1 \mathrm{~mm}^{2}$ square grid with $5 \mu \mathrm{m}$ mesh size and an average $0.5 \mu \mathrm{m}$ grid line was obtained by a photoresist technique, using the beam of a SEM. Our observations, pointed out that (Fig.2) :

- macroscopical shear bands were constituted of microscopical ones

- shearing intensity was proportional to the number of microscopical bands activated inside macroscopical ones

- strain increased by elongation of inftial shear bands and nucleation of new bands in the vicinity of initial ones.

Previous works on rolled polycrystals have reported that shear bands appeared inside somme especially oriented grains. With intend to caracterize the conditions of initiation and propagation of such bands, experiments on special orfented bicrystals have been undertaken.

\section{REFERENCES}

1 D. PEIRCE J. Mech. Phys. Solids 31 (1983) 133.

2 M.A. BIOT "Mechanics of Incremental Deformations", edited by Willey (1965).

3 R. HILL and J.W. HUTCHINSON J. Mech. Phys. Solids, 23 (1975) 239.

4 D. PEIRCE et al Acta Met. 30 (1982) 1087.

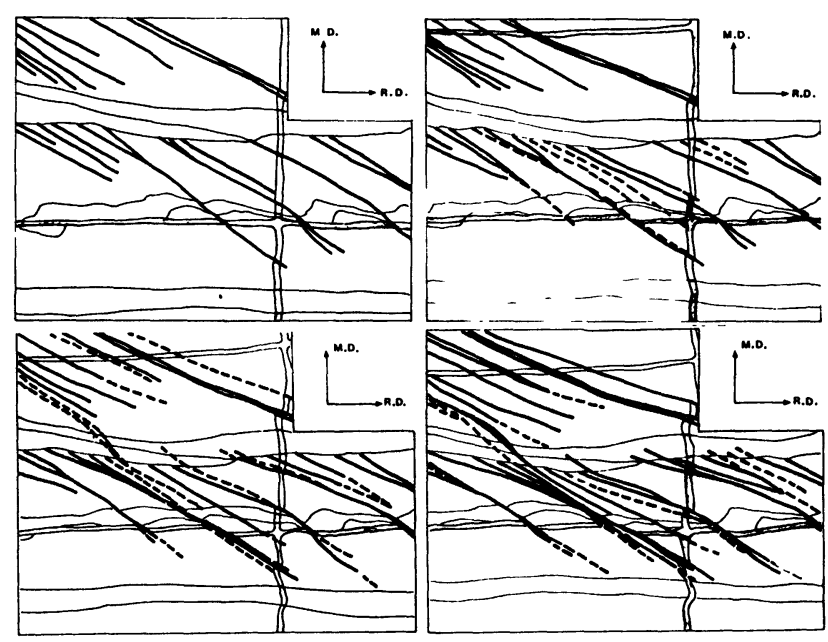

Fig. 2 Propagation of shear band in rolled polycrystals.

- Initial bands,... new bands. 